\title{
La «esclavitud» de los sentimientos: vida familiar y afectiva de la población esclava en el nororiente del Nuevo Reino de Granada, 1720-1819
}

por

\author{
Roger Pita Pico
}

Academia Colombiana de Historia

\begin{abstract}
Aún por encima de las normas establecidas en el Nuevo Reino de Granada, la posibilidad de los esclavos de entablar relaciones afectivas o de comprometerse en matrimonio siempre dependió de la voluntad y de los intereses de los amos. El cruce con personas libres también le trajo al esclavo ciertas complicaciones aunque también le abrió mayores oportunidades en su vida afectiva. El panorama para la familia esclava no era más alentador. La dinámica comercial, la manumisión y otras formas de circulación de esclavos, representaron una amenaza constante para la unidad de esas comunidades de sangre. Muchos fueron los esfuerzos y reiteradas las súplicas de los afectados por clamar mejores condiciones para llevar una vida afectiva más estable.
\end{abstract}

Palabras Clave: negros esclavos; matrimonio; familia; Colonia; Nuevo Reino de Granada.

\section{INTRODUCCIÓN}

La propuesta central de este trabajo consiste en analizar cómo las relaciones de poder y dominación, propias de la institución esclavista, afectaron la vida afectiva y familiar de la población esclava en el territorio del nororiente del Nuevo Reino de Granada, específicamente en las provincias de Girón, Socorro y Vélez ${ }^{1}$, espacio comprendido por lo que hoy se conoce como Departamento de Santander al nororiente de Colombia.

${ }^{1}$ El marco geográfico de estas provincias forma parte de la región andina. Su territorio cubre el valle del río Magdalena y su área más poblada corresponde a la vertiente de la cor- 
En esencia, el estudio se enfoca en el siglo XVIII y principios del XIX, es decir, en la última centuria del régimen colonial, cuando esta área había alcanzado un alto nivel de poblamiento que se vio reflejado en la consolidación de sus centros urbanos y en un inusitado auge de parroquias.

El desarrollo de la agricultura, la producción de lienzos y de mieles imprimieron allí una relativa prosperidad económica, particularmente notoria en la villa del Socorro ${ }^{2}$. En los campos prevaleció la pequeña y mediana propiedad, fenómeno que marcó la diferencia con otras provincias donde abundaron las grandes haciendas. Paralelo a estas dinámicas, los negros esclavos aumentaron en número, ubicándose en el medio rural en labores de cultivos y trapiches, y en el ámbito urbano, dedicados sobre todo al servicio doméstico.

Según los datos suministrados por el censo demográfico de 1778, el grupo étnico de mayor presencia en este territorio era el mestizo, con un $60 \%$ del total de la población. Le seguía, en su orden, el segmento blanco con un 30\%, mientras que indios y negros se repartían el $10 \%$ restante. La población negra representó aproximadamente el 5\% del total de habitantes, una cifra mucho más moderada de lo registrado en las provincias de Cartagena, Antioquia, Popayán y Chocó, en donde alcanzaron hasta un 30\%, llegando incluso a igualar en algunas partes a los blancos ${ }^{3}$.

Otra variable indicativa de la magnitud de la presencia esclava en esta franja nororiental fue el movimiento comercial, el cual alcanzó sus picos más altos hacia el siglo XVIII. Era un mercado pequeño dirigido a abastecer las necesidades internas, por lo tanto, no tuvo una repercusión tan directa en la economía regional. Lo anterior se debe a la escasez de minas de oro y, aunque sí fue evidente su mano de obra en los trapiches que proliferaron en jurisdicción de la ciudad de Vélez, de todas formas ese abastecimiento no fue tan considerable como el observado en otras provincias como Cartagena y Popayán. En términos generales, se daba allí una actividad comercial que no distaba mucho de las proporciones detectadas en algunas partes del interior, como en el área del altiplano que cobijaba a la capital Santa Fe y a la provincia de Tunja ${ }^{4}$.

dillera Oriental, surcada por cañones y fuertes pendientes. Su clima es muy diverso y va desde el cálido hasta el frío. Gran Atlas, 2004: 168.

2 Funcionarios, religiosos y viajeros dieron fe de este auge. Oviedo, 1990: 233, 235. Grisanti, 1951: 137.

3 Censo de población de las provincias de Tunja, Girón y Pamplona, 1778, Archivo General de la Nación, Bogotá (AGN), Censos Redimibles-Varios Departamentos, tomo 6, ff. $261 \mathrm{r}, 365 \mathrm{r}$ y $367 \mathrm{r}$.

4 Díaz Díaz, 2001: 85-107. Rueda Méndez, 1995: 47-87. 
En esta ocasión, solo se abordará el tema de las uniones intraetnia aunque cabe reconocer por anticipado que, en su mezcla con el elemento blanco e indígena, el esclavo también estuvo sometido a constantes limitaciones y señalamientos. Los casos más sonados tenían que ver cuando los amos usaban de sus esclavas, situación esta marcada por los celos y los consecuentes pleitos por la súbita aparición de hijos producto de esos cruces prohibidos ${ }^{5}$. Estas relaciones fueron objeto de especial escándalo y estigmatización, en las que no faltaron los rumores, los odios y las rivalidades.

No hay duda de que en la región objeto de este estudio primó más el cruce del elemento negro con el blanco y con el mestizo. Así lo sugieren las descripciones fenotípicas plasmadas en los documentos de la época, en las que se advierte un proceso progresivo de blanqueamiento de la comunidad negra: mulato blanco, mulato rubio, ojos claros, blanquizco, moreno claro, color amarillo, pelo liso, etc. De una muestra de 527 esclavos hallados en los archivos notariales de Girón, Socorro y Vélez, sobre quienes se especificó su color de piel, se pudo determinar que el $67 \%$ eran mulatos, el $20 \%$ negros, el $3 \%$ zambos y un $10 \%$ de otros matices ${ }^{6}$. Esa tendencia creciente al mestizaje con el elemento blanco pudo responder también a las aspiraciones de ascenso social y a las dificultades para mantener relaciones con los de su misma condición?

En realidad, en el nororiente neogranadino no fueron tan numerosas las uniones entre negros e indios, como sí sucedió en las provincias de Santa Marta y Cartagena bajo la fórmula del arrochelamiento ${ }^{8}$. Pese a la política segregacionista vigente ${ }^{9}$, el zambaje alcanzó a tener algunas expresiones mediante contactos interraciales en pueblos indígenas y en las estancias donde los indios rendían su trabajo en calidad de concertados. Otros encuentros sucedieron a expensas de las vecindades entre resguardos y propiedades rurales con presencia de esclavos, o en torno a la furtiva presencia de libertos en tierras de indios. En los centros urbanos también fue factible localizar este

5 Para el territorio objeto de este estudio, Pita Pico, 336 (Bucaramanga, 2007): 3-20. Sobre otras provincias neogranadinas, véanse Navarrete, VII/15 (Bogotá, 2003): 91-99. Jaramillo Uribe, I/1 (Bogotá, 1963): 35-38. Romero Jaramillo, 1997: 113-116.

6 Escrituras de venta de esclavos en Girón, 1720-1819, Centro de Documentación e Investigación Histórico-Regional adscrito a la UIS, Bucaramanga (CDIHR), Archivo Notarial de Girón, tomos 2-30. Escrituras de venta de esclavos en Socorro, 1720-1819, Casa de la Cultura Horacio Rodríguez Plata, Socorro (CCHRP), Archivo Notaría 1. ${ }^{\text {a }}$ del Socorro, tomos 3-39.

7 Gonzalbo Aizpuru, 1998: 219.

8 Palacios de La Vega, 1994. Herrera Ángel, 2002: 203-248.

9 Mörner, 1970: 96; I/1 (Bogotá, 1963): 64. 
tipo de maridaje donde confluyeron para desempeñar oficios domésticos, tal como se pudo corroborar en el censo de población levantado en 1778. En Girón, por ejemplo, se encontró en la residencia de la viuda doña Leonor de Armas a una esclava unida con un indio ${ }^{10}$.

Sin embargo, las cifras revelan que estos cruces fueron cada vez más escasos por cuenta de la merma demográfica indígena, la estrepitosa reducción de resguardos ${ }^{11}$ y el intenso mestizaje. Una prueba irrebatible de ello es que de los 114 matrimonios de esclavos registrados en la parroquia de Nuestra Señora del Socorro entre 1720 y 1819 , apenas cinco se consumaron con integrantes de la raza nativa ${ }^{12}$.

\section{LIMITACIONES EN LAS UNIONES MARITALES ENTRE ESCLAVOS}

En el siglo XVIII, el matrimonio católico se constituyó en el conducto principal para difundir los preceptos morales y culturales de Occidente en América. Sin embargo, en la práctica fueron innumerables los obstáculos que las parejas debieron enfrentar para formalizar nupcias y fundar familias. Esas dificultades se hicieron más evidentes entre la comunidad negra en razón a su estatus y a su postrera posición en la sociedad ${ }^{13}$.

La vida afectiva y familiar de los esclavos fue muy compleja y dependió de la conjugación de una multiplicidad de factores inherentes y externos. Los primeros, hacían alusión al estado del esclavo mismo, tales como su origen, su calidad étnica, su género, sus habilidades y sus condiciones de vida. Dentro de los factores externos se pueden incluir el ambiente geográfico, el tipo de espacio rural/urbano, la composición étnica de la sociedad, la economía

10 Censo de población de las provincias de Tunja, Girón y Pamplona, 1778 (AGN), Censos Redimibles-Varios Departamentos, tomo 6, f. 385r.

11 Refiriéndose al extenso territorio del Nuevo Reino, el visitador Francisco Antonio Moreno y Escandón comentaba en 1778 al virrey Manuel Antonio Flórez que, de los pueblos indígenas existentes a la llegada de los primeros conquistadores, no permanecían ni la décima parte. Específicamente para la franja nororiental, el visitador Andrés Verdugo y Oquendo dio cuenta en 1756 del drástico cambio demográfico al estimar que de los 50.000 nativos contabilizados en 1635, ahora solo se registraban 27.500. (AGN), Visitas de Boyacá, tomo 7 , f. 18 r; tomo 8, f. 878r. De más de 30 poblados indígenas identificados en el siglo XVI, para 1778 únicamente sobrevivían los resguardos de Guane y Chipatá. Martínez Garnica, 1994: 87-104.

12 Libro de partidas matrimoniales, 1720-1819 (CDIHR), Parroquia de Nuestra Señora del Socorro-Libro de Matrimonios, rollo 1855275, ítems 1-6.

13 Rodríguez, 1997: 142. 
regional, el marco normativo vigente y el carácter de las relaciones sostenidas entre amos y esclavos ${ }^{14}$.

Continuamente, la población esclava se vio amenazada por disposiciones que coartaban la libre elección de pareja y sintió inhibidas sus posibilidades de desarrollo conyugal y familiar. Solo en las fugas, en los palenques, en las rochelas y en todos aquellos espacios de vida clandestina, se puede decir que el negro contó con algún margen de libertad para unir su vida sin las habituales restricciones que le imponían su amo, el gobierno colonial y la Iglesia.

La raza ejerció una fuerte influencia como elemento determinante en la estratificación social de la América hispánica ${ }^{15}$. Desde un comienzo, tanto el poder eclesiástico como la Corona española se inclinaron en avalar preferiblemente uniones entre personas de la misma condición étnica ${ }^{16}$, teniendo para ello como asidero la política de segregación que bregaba por mantener la estructura social jerarquizada. Sobre los negros, fue más tangible el empeño por aplicar esta directriz discriminatoria, toda vez que ese grupo cargaba con el lastre de ser el de menor consideración social, dado el peso de la fuerte concepción negativa que el imaginario de la época guardaba acerca de ellos.

En 1527 fue publicada una cédula real que luego fue incorporada en la ley V, libro VII, título V de la Recopilación de Leyes de Indias, en la cual se dispuso propender por la unión entre negros «[...] porque con esto y con el amor que ternia (sic) a sus mujeres e hijos y con la orden de matrimonio sería causa de mucho sosiego dellos, y se excusarían otros pecados e inconvenientes que de lo contrario se sigue» ${ }^{17}$. Este interés por casarlos entre sí apuntaba entonces a apaciguar los sucesivos levantamientos y huidas que venían gestándose peligrosamente en forma cada vez más recurrente.

Pero la política segregacionista perdió sustento por el constante desequilibrio numérico de los sexos, el proceso gradual de blanqueamiento y la creciente liberación de esclavos. Bien es sabido que la cantidad de negras introducidas fue demasiado baja en relación con los varones, especialmente

14 Varios historiadores, entre ellos José Antonio Saco, creen que, aún con los excesos acontecidos, la actitud de los amos en la América Hispánica fue mucho más comprensiva y humana que lo observado en las posesiones inglesas.

15 Rodríguez, 1997: 159.

16 No obstante, en determinadas coyunturas, las autoridades aceptaron e incluso llegaron a promover las uniones entre integrantes de diferentes grupos étnicos. En la temprana época de conquista, la Corona avaló en la isla de La Española y en el Darién los matrimonios entre españoles y nativas por razones estratégicas, es decir, para calmar las tensiones entre los conquistadores y las comunidades indígenas. Konetzke, 1958, vol. I: 5, 61, 77.

17 Recopilación, 1973, tomo II: 285. 
en la conquista y en los albores de la empresa colonizadora ${ }^{18}$, variable que afectó el desarrollo natural de esta etnia ${ }^{19}$. Esto influyó, por ejemplo, en que los primeros incrementos de esa población de color en el Nuevo Reino de Granada obedecieran más al comercio que a la reproducción biológica de los ya existentes en estas tierras.

Las estancias y los trapiches eran escenarios en los que ordinariamente los esclavos padecieron ese desequilibrio de género ya que en muchos de esos centros de producción estaban ausentes las mujeres, quienes se encontraban dedicadas fundamentalmente al servicio doméstico.

Ese desfase terminó trastocando la vida sexual del hombre esclavo y lo llevó a rebuscar instintivamente su cónyuge, ya fuera de modo compartido o mediante relaciones de hecho ${ }^{20}$, desafiando con ello todos los controles y regulaciones oficiales. La búsqueda de pareja trascendió también las fronteras de su misma raza, con lo cual se infringía notablemente la intención de las autoridades.

Precisamente con el fin de contrarrestar estas aventuras profanas, atentatorias de la moral cristiana, la real cédula del 1 de febrero de 1570 mandó que todos los esclavos casados que se llevaran a las Indias trajeran consigo a sus familias ${ }^{21}$. De igual manera, se contemplaron medidas tendentes a lograr una importación más equitativa entre hombres y mujeres.

Solo hasta el siglo XVIII, la desproporción de género había sido prácticamente disipada, lo cual permitió alimentar las perspectivas para las uniones intraetnia. Si se mira el censo de 1778, la información sobre población esclava recogida para las jurisdicciones de Girón, Socorro, San Gil y Vélez arrojó un $47,8 \%$ de hombres frente a un $52,2 \%$ de mujeres ${ }^{22}$. Esta paridad se verificó también en el movimiento comercial operado en esos territorios a lo largo de las últimas décadas del periodo colonial (1720-1819). Para el caso de la villa del Socorro, de 1.458 piezas transadas, un 54\% correspondían al sexo femenino mientras que en Girón se contabilizaron 882 hombres frente a 761 mujeres $^{23}$.

18 Algunos cálculos indican que por cada tres negros llegados a América, arribaba una negra. Mörner, 1969: 40.

19 Klein, 1986: 99.

20 Gutiérrez y Pineda, 1999, tomo II: 371.

21 Konetzke, 1958, vol. I: 451.

22 Censo de población de las provincias de Tunja, Girón y Pamplona, 1778 (AGN), Censos Redimibles-Varios Departamentos, tomo 6, ff. 261r-367v.

23 Escrituras de venta de esclavos en Girón, 1720-1819 (CDIHR), Archivo Notarial de Girón, tomos 2-30. Escrituras de venta de esclavos en El Socorro, 1720-1819 (CCHRP), Archivo Notaría 1. a del Socorro, tomos 3-39. 
Aparte de las normas que los constreñían a mantener relaciones entre los de su misma clase, los negros también vieron reducidas sus esperanzas de contacto afectivo. La dispersión geográfica, por lo menos en lo que atañe al ámbito rural, ofrecía muy pocos escenarios de encuentro entre ambos géneros. Asimismo, las limitaciones en la libertad de movimiento regularmente subordinada al capricho del amo, el estrecho margen para el divertimento y las prolongadas y extenuantes jornadas de trabajo, eran otros agravantes que hacían menos propicio ese acercamiento.

En la cédula expedida por el rey Carlos IV el 31 de mayo de 1789, conocida también como el Código Negro Español24, fue reiterativo el afán por no consentir espacios en los que pudiera fraguarse la mezcla de los dos sexos. Era una separación que abarcaba los sitios de trabajo, los ratos dedicados al esparcimiento y hasta la misma distribución al interior de las habitaciones de descanso ${ }^{25}$.

Sin embargo, a los tres años de promulgada la ley, el Consejo de Indias se pronunció en un tono crítico. Según el sentir de este máximo órgano consultivo, esa peculiar regla se hacía ambigua al momento de aplicarse ya que, aunque podían sobrevenir acercamientos entre solteras y solteros, no había razón valedera para preocuparse por las mujeres casadas si estas andaban a la vista de sus maridos. Se argüía además que el cabal acatamiento de esta disposición podía socavar seriamente el desarrollo complementario de las faenas productivas ${ }^{26}$.

A las limitaciones ya referidas, habría que agregarle el control directo ejercido por el amo sobre la vida cotidiana y afectiva de sus servidores. Miguel Mantilla, oriundo de la parroquia de Piedecuesta en la provincia de Girón, negoció en 1815 una mulata de 25 años, previniéndole al comprador José María Ordóñez sobre el extravío «de ser demasiado afecta a los hombres» 27. En un juicio adelantado en esa misma jurisdicción, el amo Juan de Arciniegas se quejó de su esclava Tomasa porque solía abandonar sus quehaceres diarios para ir «al camino real a apreciar los hombres» ${ }^{28}$.

24 Esta ley se constituyó en el primer compendio normativo coherente en el tratamiento humanitario de la población esclava, lo cual significó un avance si se compara con las anteriores leyes de carácter marcadamente represivo.

25 Cédula Real sobre trato y protección de los esclavos, 1789 (AGN), Reales Cédulas y Órdenes, tomo 29, f. 60r.

26 Saco, 1938, tomo III: 271-272.

27 Escritura de venta de una mulata de 25 años en la ciudad de Girón, 1815 (CDIHR), Archivo Notarial de Girón, tomo 29, f. 96v. f. $981 \mathrm{r}$.

28 Juicio en Girón por maltrato a la esclava Tomasa (AGN), Criminales, tomo 28, 


\section{Los avatares del compromiso legal}

Aun cuando el negro esclavo se ciñera a las pautas normativas y se fijara en una compañera de similar condición étnica, esto no allanaba totalmente el camino para contraer nupcias. En un decreto expedido en 1527, la Corona instó a los amos a procurar que sus esclavos se casaran, pero dejándoles a estos autonomía en su elección «porque el matrimonio ha de ser libre y no premioso ${ }^{29}$.

Sin embargo, esa era una determinación que casi siempre pasaba a ser intervenida por los propietarios puesto que eran ellos quienes, en definitiva, asentían o descalificaban la potencial pareja. No en vano, solían utilizar expresiones como "casé a mi esclava», al igual que cuando se referían a sus propias hijas. Esa imposición del amo pudo ser más fuerte sobre los esclavos africanos que sobre los criollos, dada la mayor capacidad de estos para ejercer su voluntad ${ }^{30}$.

En el título I, capítulo 10 del sínodo provincial convocado en Santa $\mathrm{Fe}$ hacia 1606, se condenó - conforme a lo predispuesto en el Concilio Tridentino- cualquier intromisión al derecho natural del casamiento:

[...] a todos los señores que estorban la libertad a sus súbditos en este sacramento o en el uso de él, en la cual incurran todos los encomenderos o señores de indios y de esclavos que los estorbaren e impidieren casarse o los forzasen a casar contra su voluntad, y también los que apartaren a sus esclavos o indios de sus mujeres, de manera que no tengan entera libertad en el uso del matrimonio, además de la pena sobredicha [excomunión mayor] pagarán treinta pesos de buen oro [...] atento a que el abuso y exceso que en esto hay es tan grande, y el escándalo y daño para los indios y negros tan perjudicial y digno de remedio ${ }^{31}$.

Esta advertencia debió de ser recalcada en sucesivas oportunidades. Así se hizo en 1794 mediante una consulta elevada al Consejo de Indias, en donde se corroboró nuevamente que el esclavo podía casarse con entera libertad $^{32}$.

En otro intento, al final fallido, por hacer respetar el enlace marital entre la gente de ébano, el diputado Antonio Villavicencio presentó el 16 de noviembre de 1809 un proyecto de ley ante las Cortes de España. Allí se propuso que ningún amo podía negarle a su esclavo el permiso para contraer

\footnotetext{
29 Konetzke, 1958, vol. I: 100.

30 Gonzalbo Aizpuru, 1998: 210.

31 Constituciones, V (Bogotá, 1955): 166-167.

32 Gutiérrez y Pineda, 1999, tomo II: 34.
} 
nupcias, y además, a todos los casados se les debía tener dispuestas sus habitaciones separadas del resto de criados $^{33}$.

Las interferencias de los amos y los constantes obstáculos repercutieron de algún modo en las cifras de casados. El historiador Herbert Klein estimó que, aún en los inicios del siglo XIX, solo una décima parte de las parejas de esclavos vivían en matrimonio legal en la América hispánica ${ }^{34}$, eso a pesar de la insistencia de la Corona y de la Iglesia por promover uniones de esta índole. El mismo Código de 1789, en su capítulo séptimo, había reiterado que se debían evitar los «tratos ilícitos» entre ambos sexos, y que en su lugar, había que fomentar el matrimonio.

A nivel regional, también se puede constatar el bajo índice de bodas celebradas entre la etnia negra. En el siguiente cuadro, extraído del censo levantado en 1778, se puede advertir cómo en la provincia de Girón la tendencia a casarse era sensiblemente menor entre la población esclava en relación con las demás castas.

Cuadro 1. Número de matrimonios en la provinCia de Girón SEgún EL CENSO DE 1778

\begin{tabular}{|l|c|c|}
\hline \multicolumn{1}{|c|}{ Etnias } & Total población & N. $^{\mathbf{0}}$ matrimonios \\
\hline Blancos & 1.472 & 204 \\
\hline Libres & 4.593 & 753 \\
\hline Indios & 126 & 26 \\
\hline Esclavos & 804 & 27 \\
\hline
\end{tabular}

Fuente: (AGN), Censos Redimibles-Varios Departamentos, tomo 6, f. 367r.

Esa baja proporción de esclavos comprometidos en el sagrado vínculo del matrimonio, se explica por el tibio alcance que en realidad proyectó la Iglesia en la población negra. De todos modos, fuera cual fuera su verdadera incidencia, lo único cierto es que esta institución no desaprovechó la ocasión para imponerle al esclavo una serie de requisitos previos a la boda. Debían confesarse, saber de memoria las oraciones y mandamientos, o de lo contrario, serían sometidos a una catequización intensiva hasta que demostrasen conocer

33 Abolición de la esclavitud en ambas Américas, 1809, Biblioteca Nacional de Colombia, Bogotá (BNC), Manuscritos, libro 435, ff. 51v-52r.

34 Klein, 1986: 123. 
los misterios básicos de la fe. Se fijó además una edad mínima para adquirir ese compromiso, que en los varones debía ser de catorce años y en las mujeres de doce ${ }^{35}$.

Los mismos gastos parroquiales, ligados a la boda, pudieron convertirse en un factor desestimulante para los esclavos, por lo regular sumidos en la pobreza. En estos casos, era el propietario el llamado a la subvención, lo que de por sí recaía en él la decisión de celebrar el sagrado vínculo.

Mayor fue la tendencia de la comunidad nativa a casarse, lo cual apunta a ratificar la influencia de los preceptos católicos al interior de este grupo étnico y la mayor libertad con que sus integrantes pudieron formalizar sus vínculos maritales. En cierta medida, el hecho de vivir agrupados en resguardos pudo facilitar la acción de la labor evangelizadora.

En la práctica, fueron comunes en el negro las relaciones de hecho o esporádicas debido a las barreras para entablar una unión de largo aliento. Aquí no puede dejarse de considerar la distorsionada influencia irradiada por su amo, el hombre blanco, como paradigma de comportamiento y como preconizador del principio cristiano de matrimonio monógamo y del tradicional modelo de familia patriarcal. Para nadie era un secreto la propensión de españoles y criollos a cultivar relaciones adúlteras e incluso exogámicas ${ }^{36}$.

Más que propiciar el matrimonio entre sus esclavos, lo que más le interesaba al propietario era la reproducción por cuanto entraba a engrosar su capital $^{37} \mathrm{y}$, el mejor método para lograrlo era concediéndoles libertad sexual sin necesidad de lo dispendioso que resultaba el compromiso legal. Se sabe, por cuenta de algunas investigaciones sobre regiones esclavistas, que muchos llegaron a exigir a sus negras procrear anualmente con la amenaza que, si no cumplían, eran vendidas en las minas ${ }^{38}$.

Es bueno aclarar que en la franja nororiental no se obtuvo el mismo nivel de complejidad que se experimentó en otras latitudes del Nuevo Reino carac-

35 Constituciones, V (Bogotá, 1955): 167.

36 Gutiérrez y Pineda, 1999, tomo II: 368.

$37 \mathrm{La}$ fecunda maternidad esclava pudo ser un factor de complacencia para algunos amos al ver «naturalmente» incrementados sus patrimonios. En 1755, doña Feliciana de Archila oficializó en San Gil la libertad de su mulata Ignacia por el amor y gratitud que le profesaba, y porque además, «[...] le ha dado a ganar otros esclavos que ha parido». Uno de los motivos expuestos en esa misma villa por los herederos de doña Salvadora Tavera para manumitir a la esclava Basilia, estaba «[...] el mucho provecho que ha dado en la casa, pues al presente se hallan cinco esclavos que se han inventariado y avaluado por bienes de la dicha difunta, y a más de eso otros hijos que dicha su madre dio a sus herederos y vendió». (CCHRP), Archivo Notaría $1 .^{\text {a }}$ del Socorro, tomo 11, f. $515 \mathrm{v}$; tomo 13, f. $79 \mathrm{r}$.

38 Gutiérrez de Pineda, 1997: 281. 
terizadamente esclavistas, como Chocó y Cartagena, en donde la transgresión a la normatividad matrimonial adquirió mayúsculas dimensiones, especialmente en aquellas zonas alejadas e inhóspitas en las que se vivía relajadamente sin tanto apego a los preceptos cristianos.

Para el marco espacial objeto de este estudio, solo habría que mencionar el flanco occidental correspondiente a las cálidas riberas de la parte media del río Magdalena, en donde fue patética la falta de control y de presencia de las autoridades. El cura de la parroquia de Puente Real, fray Pedro Pardo, en su recorrido por el río Carare hacia el año de 1803, dio testimonio de la existencia de varios pardos cohabitando ilegítimamente con algunas mujeres ${ }^{39}$.

El espacio en el que se movía el esclavo, su origen y su género fueron factores que pudieron influir al momento de formalizar vínculos maritales. Al parecer, los esclavos de servicio doméstico ubicados en el área urbana gozaron de muchas más facilidades para acceder al matrimonio, en contraste con aquellos dedicados a fuertes quehaceres en estancias distantes ${ }^{40}$. Esto puede atribuirse a que en el ámbito urbano - ampliado en el siglo XVIII gracias a la erección de aproximadamente treinta parroquias - se contaba con una mayor cercanía de los servicios religiosos que podían velar por la legalización de las uniones. Eventualmente, había allí más oportunidad de contacto social, dada la concentración demográfica en una misma área y la habitual convergencia que giraba en torno a los mercados y misas dominicales.

En un comienzo, la fuerza de las circunstancias hizo que las uniones se consumaran exclusivamente entre esclavos provenientes de África, tal como sucedió con los primeros negros llevados por vecinos de las ciudades de Pamplona y Vélez a trabajar en los aluviones de Río de Oro en la segunda mitad del siglo XVI. Con el paso de las generaciones, el número de criollos entró en ascenso e inmediatamente empezaron a hacerse latentes los problemas de comunicación con los distintos dialectos y costumbres que aún conservaban sus congéneres africanos.

No obstante, progresivamente esos escollos en la comunicación fueron superados. Hacia 1718 en la ciudad de Girón, Joseph González del Busto vendió a Lorenzo de Uribe Salazar un negro criollo llamado Juan de cuaren-

39 Diario del viaje del cura Pedro Pardo, en la exploración de la vía del Carare, 18021805 (AGN), Historia Civil, tomo 13, ff. 624v-649v.

40 Durante el siglo XVII, y aún en el XVIII, se escucharon varias quejas respecto a la desatención espiritual de los esclavos en el espacio rural. Según las circunstancias, ellos debieron agregarse a doctrinas de indios ya constituidas o, cuando las condiciones económicas lo permitían, se instalaban capillas por iniciativa del esfuerzo mancomunado de estancieros y dueños de trapiches. 
ta años de edad y su mujer Teresa, de nación Loango y de aproximadamente dieciséis años ${ }^{41}$. A lo último, casos como estos fueron cada vez más atípicos y reflejos de una etapa transitoria puesto que terminaron imperando los enlaces entre los nacidos en estas tierras ${ }^{42}$.

Respecto a la proporción de solteros y casados, tal como lo ilustra el siguiente cuadro alusivo al padrón de población de 1778, se encontró — sobre la base de un equilibrio de género- que había una mayor propensión en los hombres a unir sus vidas.

Cuadro 2. Número de ESClavos CASAdos EN El NORORIENTE NEOGRANAdino SEGÚN EL CENSO DE 1778

\begin{tabular}{|l|c|c|c|c|c|}
\hline Poblaciones & $\begin{array}{c}\text { Esclavos } \\
\text { casados }\end{array}$ & Total esclavos & $\begin{array}{c}\text { Esclavas } \\
\text { casadas }\end{array}$ & Total esclavas & $\begin{array}{c}\text { Total } \\
\text { población } \\
\text { esclava }\end{array}$ \\
\hline Girón & 34 & 380 & 27 & 424 & 804 \\
\hline Vélez & 296 & 708 & 152 & 649 & 1.357 \\
\hline Socorro & 210 & 848 & 197 & 1.000 & 1.848 \\
\hline San Gil & 38 & 214 & 39 & 277 & 491 \\
\hline Total & 578 & 2.150 & 415 & 2.350 & 4.500 \\
\hline
\end{tabular}

Fuente: (AGN), Censos Redimibles-Varios Departamentos, tomo 6, ff. 261r y 367r.

Esa correlación se puede auscultar más en detalle en la descripción individual llevada a cabo en las localidades de Girón y Piedecuesta. Tal proporción da pie para reforzar la idea respecto a la mayor movilidad que pudo tener el hombre esclavo en razón a su trabajo. También indica el éxito del género masculino en conseguir pareja por fuera de su estatus y de su etnia. Al momento de comparar estas cifras, con las registradas en el grupo indígena, se observa un mayor equilibrio en las cifras de casados según el género, registrándose 548 hombres y 538 mujeres comprometidas.

Es básico tener en cuenta que la idea del matrimonio implicaba una confrontación con el régimen esclavista mismo, puesto que inmediatamente llevaba a reflexionar sobre cómo descifrar el dilema de conservar la unión sin

${ }^{41}$ Escritura de venta del negro Juan en la ciudad de Girón, 1718 (CDIHR), Archivo Notarial de Girón, tomo 2, f. 235r.

42 Para el periodo estudiado (1720-1819), en el mercado de Girón y Socorro el predominio de los esclavos criollos fue casi absoluto ya que llegaba al $98 \%$. 
que cada uno dejara de servir a su respectivo propietario. Para solucionar tempranamente ese aprieto, Las Siete Partidas promulgadas en el siglo XIII por el rey Alfonso El Sabio, presionaron al amo a tener que comprar la novia escogida por su esclavo y a vender unida la pareja ya constituida ${ }^{43}$, con lo cual se pretendía respetar el domicilio conyugal y no apartar el vínculo ni la venidera descendencia.

Mucho más adelante, la ya citada cédula real de 1789 explicó en forma más desmenuzada el procedimiento que se debía seguir para estos efectos:

[...] si las haciendas estuvieren distantes de modo que no puedan cumplir los consortes con el fin del matrimonio, seguirá la mujer al marido, comprándola el dueño de éste a justa tasación de peritos nombrados por las partes y por el tercero que en caso de discordia nombrará la justicia; y si el dueño del marido no se conviene en la compra, tendrá la misma acción el que lo fuere de la mujer ${ }^{44}$.

Pero en la práctica, esta instrucción no contó con la mejor acogida por parte de los propietarios, quienes temieron en la aceptación del matrimonio de sus esclavos un costo adicional que muchas veces no estaban dispuestos a solventar. Fuera este u otro el motivo, lo cierto es que hay pruebas que revelan el desacato o relajamiento frente a esa orden.

Ante el pálido incentivo para impulsar la fórmula de vínculo sacramental, los amos hábilmente visualizaron las ventajas de ser laxos con las relaciones de hecho, puesto que así no se verían precisados a sostener la pareja casada. Es decir, al espíritu de la ley se interpuso la conveniencia y arbitrio del propietario.

Al final, la experiencia muestra que algunas parejas eran distanciadas a veces con la incertidumbre de no volver a juntar nunca más sus vidas. Con ello, los amos entorpecían la indisolubilidad y la unidad habitacional como ejes rectores del matrimonio cristiano. A esto se le añadió el hecho de que la reacción de las autoridades ante estas iniquidades dejaba en realidad mucho que desear.

No obstante, al otro extremo, aunque de manera menos frecuente, existieron dueños comprensibles que no ocultaron su preocupación por el futuro y perdurabilidad de la alianza matrimonial de sus servidores. Pruebas de ello son algunas precisiones estipuladas en las escrituras de venta, expresiones que bien podían ser el resultado del afecto y de la gratitud profesada hacia los servidores esclavos. El vecino gironés don N. Benítez prometió no vender a su esclavo Francisco «mientras dure su matrimonio» ${ }^{45}$.

43 Siete, 1846, tomo II: 18-20.

44 Cédula Real sobre trato y protección de los esclavos, 1789 (AGN), Reales Cédulas y Órdenes, tomo 29, f. 61r.

45 Ruiz Hernández, 1994: 102. 
Al momento en que don Joseph Calderón cerró trato en 1779 con el procurador de Girón don Nicolás del Villar para venderle la esclava Marcelina con su pequeño hijo de un año, tuvo la precaución de sentar la siguiente aclaración: «[...] ser ésta casada con esclavo de otro dueño» ${ }^{46}$. En esa misma jurisdicción, don Marcos Gutiérrez negoció su joven esclavo Casimiro, pero no sin antes dejar muy en claro la «condición de que es casado y de que, en caso de que haya de venderlo, es obligado a vender la mulata a cualesquiera que comprase al negro» ${ }^{47}$.

Fueron claves en estos procesos de unión los acuerdos previos concretados por los amos contratantes. En septiembre de 1800, don Agustín Mantilla y Arenas, feligrés de la parroquia de Piedecuesta, ofreció su mulata María de dieciocho años «[...] con declaración de que ha sido compelido por el comprador en demanda que tuvieron, a fin de que se la vendiera o le comprase un mulato, por tener éstos tratado casamiento para que de este modo lo verificasen sin impedimentos» ${ }^{48}$. En otras circunstancias, esa intención de garantizar vida maridable aparecía un tanto implícita. En febrero de 1783, doña María Josefa de Olarte y Flórez vendió en Vélez a su hermano Juan Bauptista la negra María Teresa por un valor de 300 pesos. En algunas líneas del documento en que quedó oficializada la transacción, se puso de presente que la esclava se hallaba formalmente casada con Lorenzo, esclavo perteneciente al dicho comprador. De lo anterior, se deduce entonces que la pareja quedaría juntada bajo un mismo techo luego de sellada la transacción ${ }^{49}$.

A través de la manumisión, también se abrieron nuevas posibilidades de unión conyugal. En el episodio que se reseña a continuación, la vecina socorrana Bruna Plata premió en 1813 a su esclava Josefa por sus esmerados servicios, permitiéndole simultáneamente gozar de una vida conyugal libre de ataduras: «[...] y que habiéndole hecho presente que deseaba contraer el sagrado vínculo del matrimonio, ha tenido a bien conceder no solo la facultad para casarse sino también su plena y perfecta libertad natural [...] con la condición de no poder salir de la casa de la otorgante y de estar sujeta a sus órdenes hasta que realice el matrimonio del cual, si pueda tener hijos, deben entenderse libres $\rangle^{50}$.

46 Escritura de venta de la esclava Marcelina y su hijo de un año, 1779 (CDIHR), Archivo Notarial de Girón, tomo 14, f. 281r.

47 Ibidem, f. 77r.

48 Escritura de venta de la mulata María de 18 años de edad, 1800 (CDIHR), Archivo Notarial de Girón, tomo 22, f. 65v.

49 Escritura de venta de la negra María Teresa, 1783, Notaría Primera de Vélez, Vélez (NPV), Archivo Notarial de Vélez, tomo 73, ff. 246v-247v.

50 Escritura de venta de la esclava Josefa, de propiedad de Bruna Plata, 1813 (CCHRP), Archivo Notaría 1. a del Socorro, tomo 36, f. 319v. 
El apoyo de los amos a la estabilidad conyugal de sus servidores de color pudo extenderse también hacia quienes habían recibido el beneficio de la libertad. Doña Liana Gómez, y su marido el sargento mayor Juan Gómez de Andrade, criaron en Vélez a la liberta María. Esta mulata cuarterona recibió pródigas atenciones que llegaron hasta el punto de verla realizada en la vida matrimonial:

[...] y después de tener edad la puse en estado y casé con Manuel Trujillo maestro de herrero, y la vestí y le di cama, y asimismo le di por vía de limosna y gracia una casa de tapia y paja, puertas y ventanas y una fragua de herrería para uso del oficio de su marido, y asimismo dos vasos de plata, tres cucharas y una jícara guarnecida de plata, y el vestuario de su persona que se compone de saya, mantellina, y manto, como también cama de dormir que se compone de pabellón, colchón, sábanas y almohadas ${ }^{51}$.

Gómez de Andrade dejó también estipulado en su testamento, firmado en 1720, su decisión de otorgarles a los recién casados dos jóvenes esclavas para las labores hogareñas y crianza de los hijos venideros.

\section{Entrecruces esclavo-libre}

La liberación de los esclavos, que tuvo su apogeo en el siglo XVIII, ofreció posibilidades de movilidad espacial que proporcionaron una mayor independencia a la hora de mezclarse. Gracias a ello, se abría el abanico de opciones para el esclavo que no solo estaba supeditado a relacionarse con alguien de su mismo estatus de sujeción sino que podía atreverse a tener como pareja una negra o mulata ya liberta.

Este tipo de unión - al igual que aquella entre esclavos - tampoco se salvaba de la previa anuencia del dueño de la pareja esclava. En un acta de matrimonio, registrado en la parroquia de Bucaramanga en la provincia de Girón, el sacerdote aclaró que el contrayente era esclavo y la esposa libre, y que además, ese vínculo había sido bajo el consentimiento espontáneo del amo de dicho marido ${ }^{52}$.

Desde muy temprano, el Estado colonial y la Iglesia fijaron algunos condicionamientos. En el primer catecismo promulgado por el arzobispo de Santa $\mathrm{Fe}$, fray Luis Zapata de Cárdenas, quedó consignado el impedimento por «disparidad de condición» cuando se cruzaba un libre con una esclava, sien-

51 Testamento de Juan Gómez de Andrade, 1759 (AGN), Negros y Esclavos de Santander, tomo 5, f. 306r.

52 Sotelo Zárate, 2 (Bucaramanga, 2005): 23. 
do ignorante una de las partes del verdadero estatus de su compañero. En el hipotético caso de consumarse la unión, sería automáticamente anulada ${ }^{53}$.

En razón a tantas vicisitudes, era sensato asegurarse que cada quien estuviera plenamente enterado de la condición de su prometido/a. Entre los casamientos inscritos hacia 1787 en la parroquia de Nuestra Señora del Socorro, se anotó uno en el cual la mujer libre María Ramírez confesó ser «sabedora de la esclavitud de su consorte» Juan de Dios ${ }^{54}$.

De vez en cuando, en las escrituras de compra-venta de esclavos también se dejaba constancia del estatus heterogéneo de las parejas. Por esos mismos años, en la parroquia de Guadalupe ubicada en la provincia de Vélez, don Gregorio Tello y Zárate vendió al mulato Tomás «[...] con declaración que el referido esclavo es casado y velado con mujer libre» $\rangle^{55}$.

También en este tipo de vínculos surgió el dilema de cómo preservar unida la pareja. Fue así como la ley, basada en el paradigma de la unidad conyugal preconizada por el cristianismo, dispuso que la mujer liberta pasara al hogar o propiedad donde residía su pareja esclava y debía además rendirle servicio al dueño ${ }^{56}$. Como era apenas lógico, este mandato no demoró en suscitar complicaciones, tanto para el amo como para los propios contrayentes.

Algunas libres, en su interés por permanecer al lado de sus cónyuges, trabajaron en casa de los amos de estos, pero sin recibir la correspondiente remuneración. Otras debieron afrontar una encrucijada peor ante la infundada ambición del propietario por considerarlas con el mismo rasero esclavista, tanto a ellas como a sus hijos.

No fueron pocas las voces que señalaron estas y otras tantas tensiones que se cernían sobre este maridaje. A este respecto, cabe citar un comentario plasmado en 1792 por el Padre Eloy Valenzuela en el libro de registro de partidas matrimoniales de la parroquia de San Laureano de Bucaramanga:

[...] ningunos casamientos hay peores que los desiguales de un libre y una esclava, por lo muy expuestos al divorcio o bien por los diferentes amos a que pase la esclava, cuya servidumbre no quieren experimentar los maridos y muchas veces ni aun vivir en casas; bien por no esclavizar su sangre en los hijos que producen para

\footnotetext{
53 Zapata de Cárdenas, 1988: 79.

${ }_{54}$ Matrimonios registrados en El Socorro, 1787 (CDIHR), Parroquia de Nuestra Señora del Socorro-Libro de Matrimonios, rollo 1855275, ítem 4, f. $26 \mathrm{v}$.

55 Escritura de venta del esclavo Tomás en la parroquia de Guadalupe, 1789 (NPV), Archivo Notarial de Vélez, tomo año 1805, f. 428r.

56 Gutiérrez y Pineda, 1999, tomo II: 375.
} 
los amos, cuyo respeto es capaz de inclinar a muchas maldades en el porte con sus consortes $^{57}$.

Para ilustrar más sobre esta problemática, bien vale la pena traer a colación una trama ocurrida en la villa de San Gil donde María Pastora Mendoza, negra manumisa y mujer del esclavo Rafael Santaya, reclamó en 1798 la dignidad de libres para sus siete hijos y tres nietos que eran tratados injustamente por don José María Suárez, amo de su esposo. El procurador elevó ante las autoridades la respectiva queja: «[...] toda esta familia pretende esclavizarla prevalido en el color negro en que han nacido, castigándole con más rigor del que es permitido a los verdaderos esclavos, tratándolos de vender sobre cuyo particular acudió a uno de los alcaldes ordinarios quien se excusó a hacerle justicia $[. .].\rangle^{58}$, por ser este hermano del acusado.

Se observó en este caso la negligencia de los jueces locales para actuar en Derecho, lo que indujo a la referida negra a tomar la decisión de huir junto con su marido a Santa Fe en busca de pronta solución a su requerimiento. Después de múltiples obstáculos interpuestos por el amo José María, y al no poder comprobar su título de propiedad, la Real Audiencia se pronunció ordenándole abstenerse de ejercer el señorío sobre ella y su progenie y mucho menos tratar de venderlos.

Por otro lado, en esta clase de uniones el amo percibía cierta dificultad al momento de vender a su esclavo casado ya que estaba la presión de ceder también su familia libre, lo cual podía representar una carga adicional para el nuevo propietario. Cuando corría el año de 1764 en San Gil, la esclava Francisca se fugó de la casa de su ama, la viuda doña Margarita Ferreira. La causa para haber tomado tan radical decisión fueron los excesivos e insufribles maltratos, pero principalmente porque su dueña no consentía que ella habitara con su marido libre. Esta situación la obligó a suplicarle al presbítero Juan Antonio Bautista de los Reyes para que la comprara y, a pesar de haber este accedido, la viuda se opuso rotundamente bajo el entendido de que a ella como legítima propietaria le asistía la entera potestad de venderla a quien quisiera $\mathrm{y}$ en el momento que quisiera.

Desde mucho antes, doña Margarita le había advertido a la pareja de su criada que buscara donde trabajar porque en la casa no lo necesitaba. Pese a este rechazo, la mulata no se rindió en su intento y optó entonces por acudir ante la Real Justicia para que se le autorizara el cambio de amo, todo con

57 Citado en: Gutiérrez y Pineda, 1999, tomo I: 120.

58 Pastora Mendoza reclama la condición de libres para sus hijos y nietos, 1799 (AGN), Negros y Esclavos de Santander, tomo 4, f. 388r. 
miras a lograr que «el santo sacramento del matrimonio no padeciera perjuicio» ${ }^{59}$.

Al margen de las adversidades que pudieran emerger, estos casamientos también vinieron acompañados de algunos beneficios para las familias resultantes puesto que, cuando se llevaban a cabo entre dos personas esclavas, los hijos nacían con el mismo estatus mientras que, a la luz de lo contemplado por la ley de vientres, si la escogida era una negra o mulata ya liberta, los descendientes podían heredar ese privilegio.

Atenidos a tal circunstancia, algunos amos se mostraron renuentes a aprobar este último tipo de enlace marital puesto que le impedía acrecentar su capital de esclavos, y además, podía acarrearle gastos de sostenimiento no previstos. Esto, de algún modo, pudo incidir para que terminaran inclinándose en promocionar casamientos entre mujeres esclavas y hombres libres ${ }^{60}$.

Por otra parte, el hecho de haber uno en la pareja que fuera libre pudo eventualmente ampliar las ilusiones de prosperidad y movilidad económica. De esta manera, resultaba más expedito el camino para desarrollar otras actividades productivas o adquirir bienes propios que se constituían en un alivio al momento de mejorar las perspectivas de supervivencia. En tal sentido, la consecución de una pareja libre pudo convertirse en un nuevo incentivo económico y en una oportunidad para vislumbrar unas condiciones de vida más halagüeñas.

Se sabe además que algunos libertos trataron por todos los medios de comprar la libertad de su cónyuge, para así disfrutar ambos de una convivencia matrimonial sin ataduras. Si se analizan los datos disponibles sobre manumisiones pagadas en la provincia de Girón durante el periodo 1720-1819, se observa que, si bien es cierto que primó la tendencia de procurar la libertad de los hijos, de todas formas un $8,4 \%$ de los casos inventariados eran esposos en busca de la emancipación de sus compañeras ${ }^{61}$.

Ocasionalmente, los mismos amos abrieron a futuro esa posibilidad de rescate. En el numeral 74 del testamento firmado por el gironés don Josef Ignacio Serrano cuando corría el año de 1809, se oficializó la libertad de su negro Claudio que se hallaba enmaridado con la esclava Encarnación. Sin embargo, este propietario sembró la esperanza de que ella pudiera gozar tam-

59 Expediente sobre solicitud de cambio de amo para la esclava Francisca, 1764, Archivo Municipal de San Gil, San Gil (AMSG), Fondo Tribunal Superior de San Gil, caja 4, ff. $1 \mathrm{r}-7 \mathrm{r}$.

60 Gutiérrez y Pineda, 1999, tomo II: 349.

61 Manumisiones otorgadas en la ciudad de Girón, 1720-1819 (CDIHR), Archivo Notarial de Girón, tomos 2-30. 
bién del mismo favor: «[...] y si el dicho esclavo facilitare con qué librar a la referida su mujer, no se le impedirá» ${ }^{62}$.

Algunas fuentes examinadas permiten inferir preliminarmente que esta unión con pareja libre fue una de las opciones más deseables para los esclavos. Así se confirmó en los datos arrojados por el censo de 1778 en donde se levantaron cálculos para tres poblaciones, que por cierto fueron las únicas en que se pudo recaudar esta información concreta. En Girón, las estadísticas indicaron que de 18 casados, solo 6 lo estaban con esclavas ${ }^{63}$. Esta tendencia se mantuvo en las décadas siguientes, tal como lo constató Liliana Fabiola Ruiz Hernández en su estudio monográfico. En los datos recogidos por ella para el periodo que va de 1790 a 1851 , se registraron 31 matrimonios entre esclavos, 85 entre esclavos y libres y únicamente 1 con indígena ${ }^{64}$.

Otra fuente que apunta a corroborar la hipótesis planteada, se obtuvo revisando los registros matrimoniales de la parroquia de Nuestra Señora del Socorro en el intervalo de tiempo comprendido entre 1720 y 1819 (ver cuadro 3). Allí se contabilizó un total de 45 esclavos unidos con mujeres esclavas, la mayoría de cuyas parejas pertenecían al mismo amo, lo cual en principio podía garantizar mayor chance de estabilidad marital. Pero más de la mitad asumió el camino de compartir sus vidas con personas en estado de libertad mientras que un ínfimo porcentaje resolvió involucrarse con exponentes de la raza india.

Cuadro 3: Matrimonios de esclavos Registrados en la iglesia de Nuestra SEÑORA DEL SOCORRO, 1720-1819

\begin{tabular}{|l|c|c|}
\hline \multicolumn{1}{|c|}{ Tipo de unión } & N. $^{\text {. }}$ uniones & \% \\
\hline Entre esclavos & 45 & 39,4 \\
\hline Esclavo con libre & 39 & 34,2 \\
\hline Esclava con libre & 25 & 21,9 \\
\hline Esclava con indio & 2 & 1,7 \\
\hline Esclavo con india & 3 & 2,6 \\
\hline Total & 114 & 100 \\
\hline
\end{tabular}

Fuente: (CDIHR), Parroquia Nuestra Señora del Socorro-Libro de Matrimonios, rollo 1855275, ítems 1-6.

62 Causa testamentaria de don Josef Ignacio Serrano, 1809 (CDIHR), Archivo Notarial de Girón, tomo 26, f. 87r.

63 Censos de población de las provincias de Tunja, Girón y Pamplona, 1778 (AGN), Censos Redimibles-Varios Departamentos, tomo 6, ff. 384r-411v; tomo 8, ff. 591r-613v.

64 Ruiz Hernández, 1994: 101. En otras provincias neogranadinas, como es el caso de las áreas costeras de Santa Marta y Riohacha, también fue palpable a finales del siglo XVIII la preferencia por pareja libre. Sæther, 2005: 116. 
En estas estadísticas se nota que la pareja predominante fue aquella constituida entre esclavo y mujer libre, una combinación provechosa para ellos porque la descendencia nacía libre, pero complicada por la propensión de los amos a subyugar a la pareja femenina.

En resumidas cuentas, esta proclividad hacia uniones entre personas de distinto estatus pudo ser reflejo de la consolidación de lazos de amistad, de identidad y de solidaridad al interior de esta comunidad de ébano, en donde al parecer la condición servil no fue un impedimento infranqueable al momento de elegir pareja. Era, sin duda, una opción en vista de las conocidas complicaciones presentadas en los casos en que ambos pretendientes eran esclavos.

\section{El DESTINO DE UNA DESCENDENCIA ESTIGMATIZADA}

La primera premisa a considerar en este tema de la familia ${ }^{65}$ es que, en la medida en que para los propietarios resultaba especialmente rentable el que sus esclavas engendraran ${ }^{66}$, era fácil entender la aceptación y motivación que se pudo ejercer para que ellas lo hicieran, así fuera bajo la fórmula de las relaciones consensuales. Así las cosas, el matrimonio y la cohesión familiar esclava dejaban de ser una prioridad para los amos.

Todo hace pensar que el número de hijos fue relativamente bajo debido a los altos índices de mortalidad infantil que reinaban en la época, y que en la población esclava solían ser aún más críticos en razón a su maltrecha situación socio-económica. También fue perceptible la idea de no procrear o cegar la vida de los descendientes para que estos no cargaran con la mácula de la esclavitud ni soportaran los desmanes que esa condición entrañaba.

Evidencias que constatan ese comportamiento se hallaron en 1805 en comarcas del Socorro. Allí causó honda conmoción la actitud asumida por la esclava Juana María de la Cruz, quien ahogó a sus dos hijas, según ella, como una fórmula para librarlas de los maltratos y abusos propinados por sus amos. Después de haberse escabullido, la misma autora del crimen tomó la determinación de entregarse ante las autoridades.

65 Son escasos los estudios sobre las familias esclavas en el Nuevo Reino de Granada. Uno de ellos es el del historiador Rafael Antonio Díaz, quien incursionó en la tipología y condiciones sociales de las familias negras en el espacio regional santafereño durante la primera mitad del siglo XVIII. Díaz Díaz, 2001: 149-164.

66 Pita Pico, 31 (Cali, 2008): 89-115. 
El escribano público y de cabildo, don Joaquín Delgadillo, registró atentamente el revelador relato de la mulata, el cual se transcribe a continuación:

[...] dijo que el motivo que hubo fue de ver que su señora doña María Victoria Plata, esposa de su referido amo, las maltrataba mucho con rejo y con palo, $[\ldots]$ y que la confesante igualmente la castigaban, y que en una de ellas fue colgada y que su amo le dio unos cuatro o cinco azotes. Preguntada por qué causa o motivo sus amos castigaban a esta y a sus hijas, dijo que su señora sin causas ni motivo las castigaba, pues que a la hora que tenía cólera con la confesante, decía que sus hijas la habían de pagar a causa de no poderle pegar a la confesante porque ésta cuando su señora le quería castigar le andaba huyendo, y que a su hijita la mayor de las ahogadas que andaba en seis o cinco años la tenía aborrecida su señora, y que cuando mandaba ésta a llamar a su señora con la dicha su hija para que viniera a comer a la cocina, la echaba a pellizcos y a palos, y que cuando ésta le iba a llevar en otras ocasiones la comida adentro a su señora, le tiraba con el plato a la cara. Y que cada instante estaba maldiciendo su señora a ésta y a sus dos hijas, y que por todas estas razones, y por no ver padecer más a sus hijas, fue que les dio muerte ${ }^{67}$.

Se quejó además de que su señora no la dejaba ir a misa y que la mantenía sin ropa, casi desnuda. En cuatro ocasiones solicitó infructuosamente el cambio de amo. Por fugarse y permanecer desaparecida durante nueve años, Juana María fue sindicada de rebeldía. Esto, junto al inhumano delito consumado, fueron suficientes requisitos para que la justicia local le impusiera la pena de último suplicio, castigo que pretendía disuadir a la población esclava de emular tan execrable comportamiento.

Empero, el procurador protector de esclavos anuló la antedicha sentencia y cuestionó denodadamente a los jueces encargados del proceso por la falta de pruebas que condujeran a conclusiones esclarecedoras sobre el maltrato de que eran objeto las chiquillas. Según su criterio, era esencial demostrar los excesos cometidos por la propietaria, pues no se podía atribuir a ninguna otra causa el desesperado impulso de una madre al arrebatarle la vida a sus dos vástagos.

Un aspecto que no se puede dejar de abordar es el de los hijos ilegítimos. Los estudios sobre ilegitimidad en la América hispánica señalan una estrecha relación entre la conducta procreativa y la condición étnica ${ }^{68}$. Esa tacha se producía cuando el padre era de otra ascendencia social o étnica, o cuando se era concebido por fuera del vínculo matrimonial. La misma rigidez de la

67 Proceso seguido en El Socorro contra la esclava María de la Cruz, 1805 (AGN), Negros y Esclavos de Santander, tomo 4, ff. 326r-327v.

68 Dueñas Vargas, 1996: 207. 
estructura social de aquel entonces presionó para que se omitiera el nombre del padre, cuando este era de ascendencia blanca, con el fin de evitar el deshonor y el escarnio público.

En los esclavos, esa condición de ilegitimidad se tornó aún más entronizada que en los blancos y en los mestizos debido, entre otros factores, a los contratiempos de ese grupo social por mantener la unión familiar, a las rigurosas censuras al contacto con otras castas y a la práctica de los amos de romper esa unidad con el comercio indiscriminado.

A la anterior conclusión se puede llegar después de escudriñar las partidas de bautismo de esclavos inscritas en la iglesia de San Juan Bautista de la ciudad de Girón entre los años 1720 y 1750 . En esta muestra se computó un total de 61 legítimos y 149 ilegítimos ${ }^{69}$. Comparativamente, ese mismo comportamiento seguía haciéndose más pronunciado en el intervalo de tiempo comprendido entre 1790 y 1819 , tal como se desprende de las pesquisas recogidas por Ruiz Hernández, las cuales arrojaron 123 legítimos y 414 ilegí$\operatorname{timos}^{70}$.

Esta línea ascendente pudo obedecer a la creciente desarticulación de la familia esclava y al progresivo blanqueamiento experimentado por este grupo social negroide. Revelaba también de una manera elocuente la marginal adscripción de la pareja negra a la institución matrimonial y un mayor interés del dueño por la procreación que por asegurar un complemento estable para su esclavo. En los manuscritos consultados es dable encontrar expresiones que denotaban ese estado de ilegitimidad, tales como: «hijo natural», «madre soltera», «padre desconocido».

Estas cifras recogidas en Girón no distan mucho de lo observado en la ciudad de Santa Fe, en donde la cantidad de población esclava era muy similar a la del nororiente neogranadino. Según el estudio de Guiomar Dueñas, en el periodo comprendido entre 1750 y 1799, el número de esclavos ilegítimos en dicha capital se ubicaba en un $78 \%{ }^{71}$.

\section{FISURAS EN LA UNIDAD FAMILIAR}

Después de atravesar el Atlántico, no fue fácil que el negro conservara sus tradiciones familiares ancestrales. Por su condición servil, él debió someterse

69 Partidas de bautismo registradas en Girón, 1720-1819 (CDIHR), Parroquia San Juan Bautista de Girón-Libro de bautismos, rollos 1524025, ítems 6-8 y 1524026, ítems 1 y 2.

70 Ruiz Hernández, 1994: tabla 15.

71 Dueñas Vargas, 1996: 241. 
a las imposiciones del Estado colonial español y de la Iglesia, instituciones que influyeron notoriamente en su vida. La sociedad también le impuso unas normas específicas en cuanto a su conducta familiar ${ }^{72}$.

No obstante, esta comunidad de ébano no siempre fue fiel receptora de los cánones impuestos sino que en determinadas circunstancias adoptó sus propias formas de solidaridad y convivencia familiar ${ }^{73}$. Eso se hizo evidente en el nororiente neogranadino en cuyo territorio ya predominaban en el siglo XVIII las generaciones de afroamericanos.

En algunas situaciones, el esclavo pudo gozar de la oportunidad de vivir en unión con su familia bajo un mismo techo, pero esa posibilidad estaba circunscrita al número de esclavos por amo. Bien es sabido que la familia esclava en el marco territorial objeto de este estudio no llegó a generalizarse, tal como pudo ser más factible de detectar en zonas con acentuada densidad de población negra como Cartagena, Chocó o Popayán.

Las estimaciones para esa franja nororiental, según el censo de 1778 y las cartas testamentarias, permiten hablar de un discreto promedio de tres esclavos por casa. Con esta proporción, la tendencia más común era hallar integradas parejas, madres solteras o pequeños grupos familiares con uno o dos hijos.

Tanto las familias extensas como la presencia de varios grupos familiares congregados en una misma vivienda fueron en realidad más la excepción que la norma. Principalmente, eran las grandes estancias, los prósperos trapiches ubicados en la provincia de Vélez y los hogares de caballeros prestantes residentes en el ámbito urbano de ciudades, villas y parroquias, los espacios que albergaron estas versiones plurales de familia. El socorrano don Sebastián Ramírez dejó en 1782 constancia en su testamento de sus catorce piezas, dentro de las cuales se contaban tres grupos familiares: los negros Isidro y Margarita con sus hijas Petronila y María Natividad, la pareja conformada por Hipólito y Magdalena con una pequeña, Eugenia casada con libre y la mulata María Antonia que estaba rodeada de sus hijos Juan Ignacio, Josef Bernardo y Tomás ${ }^{74}$.

Si se contaba con mucha suerte, la unidad familiar se mantenía incólume al momento de las ventas, de las donaciones, de las sucesiones, de los trueques, de las dotes, de las manumisiones y de todas aquellas operaciones que comprometían la circulación de esclavos. Pero en la práctica, muchos amos

\footnotetext{
72 Gutiérrez de Pineda, 1997: 156-157.

73 Gonzalbo Aizpuru, 1998: 208.

74 Testamento del socorrano don Sebastián Ramírez, 1782 (CCHRP), Archivo Notaría 1. ${ }^{a}$ del Socorro, tomo 25, f. 533r.
} 
no tuvieron reparo en disgregar a los miembros constitutivos de una misma familia como si fueran animales o cosas, generando notorias fisuras en esas comunidades.

Para ahondar mucho más en la tipología de la familia esclava, se optó por sumar los datos encontrados en el comercio de Girón y Socorro en el intervalo de tiempo comprendido entre 1720 y 1819 , dada la similitud en las tendencias ${ }^{75}$. Esto arrojó una muestra representativa de 255 entidades familiares que incluían familias completas, parejas sin hijos, madres solteras y hermanos (ver cuadro 4). Sin embargo, esta base de información no es del todo confiable puesto que la realidad cotidiana de cada una de estas células sociales pudo ser de mayores dimensiones si nos atenemos a la dislocación creada precisamente por esta clase de transacciones que respondían básica-

Cuadro. Nexos familiares en las transacciones COlECtivas de ESClavos DE LAS PROVINCIAS DE GIRÓN y SOCORRO, 1720-1819

\begin{tabular}{|l|c|c|}
\hline $\begin{array}{c}\text { Nexos familiares de grupos de } \\
\text { esclavos comercializados }\end{array}$ & $\begin{array}{c}\text { Número } \\
\text { de transacciones } \\
\text { en Girón }\end{array}$ & $\begin{array}{c}\text { Número } \\
\text { de transacciones } \\
\text { en Socorro }\end{array}$ \\
\hline Madre e hijo/a & 67 & 81 \\
\hline Madre con dos hijos & 10 & 10 \\
\hline Madre con tres hijos & 1 & 4 \\
\hline Madre con más de tres hijos & 2 & 0 \\
\hline Pareja & 25 & 28 \\
\hline Pareja con un hijo & 10 & 9 \\
\hline Pareja con dos hijos & 3 & 2 \\
\hline Pareja con tres hijos & 1 & 0 \\
\hline Pareja con más de tres hijos & 0 & 5 \\
\hline Dos hermanos & 10 & 0 \\
\hline Tres hermanos & 0 & 0 \\
\hline Más de tres hermanos & 2 & 141 \\
\hline Dos o más sin nexo familiar & 131 & \\
\hline
\end{tabular}

Fuentes: (CDIHR), Archivo Notarial de Girón, t. 2-30. (CCHRP), Archivo Notaría 1. a del Socorro, t. 3-39.

75 Escrituras de venta de esclavos en Girón, 1720-1819 (CDIHR), Archivo Notarial de Girón, tomos 2-30. Escrituras de venta de esclavos en El Socorro, 1720-1819 (CCHRP), Archivo Notaría 1. del Socorro, tomos 3-39. 
mente a la voluntad y a los intereses económicos de los amos. Aun con los vacíos expuestos, se ha seleccionado esta fuente por cuanto los censos de población y los testamentos no siempre brindan una información tan detallada sobre el tipo de vínculo filial.

La primacía misma de las transacciones individuales, que alcanzaron a representar el $86 \%$ del total, se convirtió en una amenaza latente que apartaba los lazos de sangre. Del total de 3.101 piezas comercializadas en ambas localidades, apenas un $18 \%$ fueron traspasadas junto con algún familiar. Otro punto válido de referencia es el hecho de que solo una octava parte de las transacciones constituyeron casos de familia nuclear. Tal como se visualiza en el cuadro anterior, las combinaciones más frecuentes fueron en su orden: las madres con uno o dos hijos, las parejas y las parejas con un solo hijo. Ante el alejamiento producido por el comercio, pudo servir de consuelo el hecho de que por lo general el destino de los parientes vendidos no sobrepasaba las fronteras provinciales, puesto que solo un 5\% de los negociantes de Girón y Socorro eran foráneos provenientes de la Costa Caribe, del interior del Nuevo Reino y de Venezuela.

Las evidencias permiten colegir preliminarmente que uno de los efectos del comercio en la familia esclava fue la acentuación del perfil matrifocal. De 136 grupos familiares contabilizados en el mercado de esclavos del Socorro, ellas aparecen como cabeza de familia en un $70 \%$ mientras que en la vecina Girón alcanzaron un 67\%. Esta pista, junto a las informaciones extraídas de los testamentos y de los censos, ayudan a entender por qué el madresolterismo fue un fenómeno corriente entre ese grupo poblacional.

El movimiento comercial ni siquiera respetaba el periodo de embarazo de las esclavas. En 1801, don Miguel de Vargas vendió en El Socorro a don Alberto José Montero una trigueña llamada Dominga de dieciocho años que estaba «preñada», avaluada en 200 pesos $^{76}$.

De igual manera, pequeños esclavos eran desprendidos de los brazos de sus progenitoras, dando lugar a uno de los episodios más dramáticos que pusieron de relieve la vulnerabilidad de esas familias. Casi la totalidad de los párvulos comercializados en Girón y Socorro eran hijos de esclavas residentes en la casa de sus amos, lo que demostraba la prelación del interés económico sobre la cohesión familiar. Las cifras son más que patéticas por cuanto un poco menos de la mitad de los menores de doce años eran vendidos solos, y de ellos, 14 no habían cumplido todavía el primer año de vida.

76 Escritura de venta de la trigueña Dominga de 18 años de edad, 1801 (CCHRP), Archivo Notaría 1. ${ }^{\text {a }}$ del Socorro, tomo 31, f. 273 r. 
Veamos algunos ejemplos puntuales de ello. El gironés Antonio de Sosa negoció en 1721 con Juan García de Valdivieso un mulatillo de nombre Basilio nacido en su casa, hijo de una negra esclava formada también en el mismo hogar ${ }^{77}$. Dos años más tarde, don Joseph de la Portilla y Vega, doctrinero del pueblo de Silos, traspasó al sangileño Tomás Pereira tres pequeños esclavos: Francisco de nueve años, Nicolás de siete y Andrés de cuatro, todos valorados en la suma de 370 pesos $^{78}$.

Don Martín Carlos Gómez, comisario del Santo Oficio de San Gil, vendió en 1727 a María López Paredes un infante de apenas tres años «[...] el cual es procedido de una esclava llamada María que tiene el señor otorgante en su poder ${ }^{79}$. Hacia 1778 en la parroquia de Puente Real, don Francisco Franco y Pinzón negoció la bebé Ana Pía de dos años y medio, de quien se precisó era «hija de una mulata esclava llamada Antonia que vendió el otorgante ( $\sin$ la cría que ahora vende) a don Santiago Pinzón y Santos» ${ }^{80}$.

Pero incluso hay historias verdaderamente inquietantes que comprometían a criaturas de escasos meses, una edad prematura susceptible de inmensas dificultades que se hacían aún más sensibles sin la compañía y el cuidado cercano de sus madres. En 1752, la viuda socorrana doña Josefa de Uribe Franco separó al pequeño mulato Julián Antonio de tan solo dos meses del regazo de su madre, con la intención de donarlo a una sobrina en señal de agradecimiento $^{81}$.

Siendo conscientes del impacto de la dinámica comercial en la comunidad esclava, resultaba mucho más extraño aún que integrantes de tres generaciones pudieran preservar intacta su unión. En Vélez se halló uno de estos casos cuando en 1796 Isabel María de Ariza decidió vender tres de sus esclavas: «[...] la una llamada Antonia de edad de cuarenta años poco mas o menos, otra su hija nombrada Juana de dieciocho años y una hija de esta al pecho llamada María de la Cruz» ${ }^{82}$. Quedaba aquí al descubierto una gran paradoja,

77 Escritura de venta del mulato Basilio, 1721 (CDIHR), Archivo Notarial de Girón, tomo 2, f. 323r.

78 Escritura de venta de los esclavos Francisco, Nicolás y Andrés, 1723 (CCHRP), Archivo Notaría 1. ${ }^{a}$ del Socorro, tomo 2, f. 350r.

79 Escritura de venta de un mulato de tres años en El Socorro, 1727 (CCHRP), Archivo Notaría 1. ${ }^{\mathrm{a}}$ del Socorro, tomo 4, f. $193 \mathrm{v}$.

${ }^{80}$ Escritura de venta de la esclava Ana Pía de dos años de edad, 1778 (NPV), Archivo Notarial de Vélez, tomo 80, f. 134r.

81 Escritura de donación del mulato Julián Antonio de dos meses, 1752 (CCHRP), Archivo Notaría 1. a del Socorro, tomo 10, ff. 639v-640r.

82 Escritura de venta de las esclavas Antonia, Juana y María de la Cruz, 1796 (NPV), Archivo Notarial de Vélez, tomo 101, f. 314r. 
en la medida que se mantenía vivo el contacto de la línea generacional, pero en medio de un ambiente de descomposición familiar.

Tras verse afectados, algunos esclavos tuvieron la valentía de suplicar concesiones de sus amos para preservar la cercanía filial. Ante las intenciones del amo Roque Riveros de ofrecer hacia 1802 en Girón una pareja de esclavos por algunos líos en que terminaron inmiscuidos, estos invocaron la clemencia de las autoridades para que se les atendiera la siguiente petición: «[...] se ha de servir la acreditada justificación de V. Md. mandar, que de vendernos, sea con nuestros hijos» ${ }^{83}$.

Al igual que esta actividad comercial, la manumisión también trajo situaciones contrastantes en relación con la preservación de la unidad familiar esclava. En aras de la benevolencia, se optaba en ciertas ocasiones por cobijar a las generaciones venideras con el beneficio de gozar de una vida libre de ataduras. Así lo estipuló en 1749 la viuda doña Marcela Tello de Mayorga cuando acudió ante el escribano público de la villa de San Gil para pactar la libertad de sus esclavas Francisca y María Lorenza, gracia que se haría solo efectiva hasta el fin de los días de la propietaria. Adicionalmente, se contempló un valioso consuelo: «[...] y asimismo declara que si antes de su fallecimiento alguna de ellas esclavas parieren y tuviesen hijos, sean asimismo libres porque desde ahora declara por libres sus vientres que lo sean lo que de ellas produjeren $\rangle^{84}$. En 1817, doña Bárbara Salas dejó consignado en su testamento su voluntad de liberar a la pareja de Juan José y Nieves, junto a todos sus cuatro hijos ${ }^{85}$.

Pero el sentimiento de gratitud, exteriorizado por el amo a través de su disposición de autorizar la libertad a quien le había servido por años, traía a veces inhumanas determinaciones cuando no alcanzaba a cubrir la descendencia del beneficiado. De hecho, hubo episodios en que se manumitía de manera separada, lo cual podía resquebrajar aún más la ya dislocada estructura familiar esclava.

Don Francisco García Pimentel, feligrés de la parroquia de Oiba, anotó lo siguiente en su testamento fechado en 1758: «[...] que mi mulata Leonarda me ha sido buena esclava y me ha dado mucho provecho, y en remuneración de su buen servicio y voluntad le tengo ofrecida su libertad, la cual dejo libre excepto la cría que pariere por hallarse en cinta» ${ }^{86}$.

83 Escritura de venta de una pareja de esclavos en Girón, 1802 (CDIHR), Archivo Judicial de Girón, caja 40, f. 405r.

${ }^{84}$ Carta de manumisión de las esclavas Francisca y María Lorenza, 1749 (CCHRP), Archivo Notaría 1. ${ }^{a}$ del Socorro, tomo 8, f. 642v.

85 Carta de manumisión de Juan José y su esposa Nieves, 1817 (CDIHR), Archivo Notarial de Girón, tomo 29,

86 Testamento de don Francisco García Pimentel, 1758 (AGN), Testamentarias de Cundinamarca, tomo 14 , f. $901 \mathrm{v}$. 
El mismo hecho de tener una familia condujo a los esclavos a nuevas obligaciones e innatos deseos de compartir al máximo con sus seres queridos. Pero el estado de sujeción en que se desenvolvían sus vidas, era sin duda una cortapisa que había que afrontar. Hacia 1725 en El Socorro, Martín de Arenas elevó ante su amo el siguiente clamor: «[...] por haberse casado y tener hijos, le había rogado por duplicadas veces le diese carta de libertad» ${ }^{87}$. Al final, el mulato pudo abrazar felizmente su propósito.

La costumbre de algunos amos de anunciar la libertad de sus esclavos, pero supeditándola a ciertos compromisos dilatados en el tiempo, le adicionó un ingrediente más de incertidumbre a la aspiración de estos servidores de vivir en unión con los suyos. Bastante complejos resultaron también los casos en que los dueños tenían hijos con sus esclavas. Por lo general, estos pequeños solo venían a revelarse al momento de la muerte de sus padres. En Vélez, don Pedro Chacón Arroyo dejó estipulado en su testamento que liberaba «por justas causas y respetos que a ellos me mueven», a los pequeños Bernardo y Micaela, habidos de la relación con su negra Antonia. No obstante, a ella no se le reconoció el mismo beneficio pese a la supuesta promesa que dijo haberle hecho el propio Chacón ${ }^{88}$.

En cierto sentido, la libertad ofrecía una inestimable oportunidad para restablecer el vínculo y recomponer la solidaridad familiar después de los estragos provocados por los desafueros y las restricciones propias del dominio esclavista. Es en ese contexto donde adquiere relevancia el interés de los libertos por hacer ingentes esfuerzos económicos con tal de rescatar a sus seres queridos mediante el mecanismo de la manumisión por compra. Eso, se vio reflejado en los registros notariales de la ciudad de Girón entre los años 1720 y 1819. Allí, prácticamente la mitad de los 71 documentos de compra de libertad correspondía a la iniciativa de quienes querían liberar a padres, madres, esposos, hijos, hermanos, tíos o abuelos. Vale la pena mencionar algunos casos que constatan la interesante faceta de comunión de esfuerzos entre integrantes de este grupo étnico con miras a lograr ese cometido.

Trabajando con mucha «solicitud» pudo el mulato Julián Prieto reunir los 400 pesos en que fueron tasados su esposa Melchora y su pequeño vástago de dos años. Fue así como entregó ese monto a su ama doña María Pérez

87 Carta de manumisión del esclavo Martín de Arenas, 1725 (CCHRP), Archivo Notaría 1. ${ }^{\mathrm{a}}$ del Socorro, tomo 3, f. 496r.

88 Antonia Chacón, su pleito por su liberación y la de sus hijos, 1675 (AGN), Negros y Esclavos de Bolívar, tomo 6, ff. 744r-783v. 
Moreira, quien en agosto de 1728 otorgó en Girón la respectiva carta de libertad $^{89}$.

En 1760, Pedro Suárez, negro liberto habitante del valle de Suratá, se enteró de que su hijo mulato bautizado con el nombre de Julián había sido rematado en pública almoneda en la ciudad de Pamplona junto con otros bienes mortuorios del presbítero Agustín Redondo de los Ríos, diligencias hechas con el fin de cumplir a algunos acreedores del religioso.

$\mathrm{Al}$ conocer que don Ignacio de Villamizar había sido el triunfador de la subasta, ofreciendo doscientos sesenta patacones por el esclavo, Suárez corrió a suplicarle que no hiciera efectiva tal consignación, cuya demora le permitiría en calidad de padre el chance de adelantársele en el pago de esa misma suma de dinero para comprar la libertad de su propio hijo. Finalmente, Villamizar entendió la justa petición del progenitor y al cabo de unos cuantos días se oficializaron ante escribano público las gestiones que culminaron con la adjudicación de la respectiva carta de libertad ${ }^{90}$.

Por esos mismos años, el socorrano Andrés Egidio de Ardila prometió a la mulata liberta Ignacia que, si le conseguía 50 pesos, manumitiría a su hijo de doce años. Ella así lo hizo y el amo en devoción a su palabra protocolizó ante el alcalde de San Gil la correspondiente escritura de manumisión ${ }^{91}$. Hacia 1770, María Josefa y Petronila de Ardila aceptaron en El Socorro la compra de libertad de su mulato en 250 pesos que fueron recolectados por él mismo y por sus dos hermanos ${ }^{92}$.

En la parroquia de Puente Real, la mulata liberta Bárbara Pinzón compró en 1804 la libertad de su hija Antonia de 8 años, para lo cual pagó 75 pesos a su ama doña Margarita Beltrán Pinzón. Según la madre, su intención con este rescate no era otra distinta a la de asegurar el «bienestar» de su pequeña ${ }^{93}$.

Pese a todos los esfuerzos de los esclavos y de los parientes benefactores, esta modalidad de manumisión no estaba exenta de escollos. El estrecho régimen de dominación ofrecía pocos márgenes para conseguir tal concesión. Cualquiera que fuera el método para reunir dineros propios, siempre dependió de la flexibilidad y permisividad del amo.

89 Carta de manumisión de la esclava Melchora, 1728 (CDIHR), Archivo Notarial de Girón, tomo 3, f. 406.

90 Matos Hurtado, 1948: 159-163.

91 La mulata Ignacia compra la libertad de su hijo, 1768 (CCHRP), Archivo Notaría 1. ${ }^{a}$ del Socorro, tomo 16, f. 631r.

92 Manumisión por compra de un esclavo en El Socorro, 1770 (CCHRP), Archivo Notaría $1 .^{\text {a }}$ del Socorro, tomo 17 , f. 859 r.

93 La liberta Bárbara compra la libertad de su hija Antonia, 1804 (NPV), Archivo Notarial de Vélez, tomo 106, f. 263r. 
La dificultad de los esclavos para establecer negocios, el hecho de que los amos no les pagaban su trabajo extra y la negativa a dejarles usufructuar los días de fiesta para beneficio propio, eran factores que hacían utópica esa meta. Algunos, que alcanzaron el permiso para trabajar en los días feriados, debían aprovechar esas nimias ganancias para satisfacer necesidades básicas que no eran suministradas oportunamente por sus señores.

La imposición de un precio alto de liberación y el desconocimiento de los saldos abonados por el esclavo con el fin de apropiarse de ellos, fueron otros de los inconvenientes sorteados. A esto había que agregarle la maliciosa pretensión del amo de incautarle a su negro los bienes que había adquirido con harto tesón, contraviniendo con ello la ley que ya le había brindado la posibilidad de ser propietario, con lo cual se quería perpetuar la tradicional práctica de que todo aquello que poseía el esclavo le pertenecía automáticamente a su señor ${ }^{94}$. Aun si lograban amasar la cantidad requerida para su rescate, los esclavos debieron lidiar con el engaño de sus amos, quienes al tener en sus manos el monto del capital, se oponían sistemáticamente a concederles el alivio.

También hubo situaciones en las que el dueño declaraba nunca haber recibido los fondos o recurría a acusar al esclavo de obtenerlos con expoliaciones perpetradas contra él. Esto obedecía a la misma predisposición de mirar con sospecha cualquier dinero atesorado por estos servidores y a la frecuente tacha de ladrones que solía endilgárseles en virtud a la imagen negativa que de ellos se tenía.

Bonifacia, mujer libre y soltera residente en Girón, debió padecer estos obstáculos tras solicitar la compra de la libertad de su padre Pedro Román, sumido ya en la senilidad y abrumado por innumerables achaques. Para cumplir con tal meta, ella ofreció empeñar una modesta casa de teja y un pedazo de tierra en el valle del río Sogamoso con 300 árboles de cacao.

Ante la propuesta, la viuda Paulina Rodríguez se opuso de manera rotunda a otorgar la carta. Su principal argumento era que Pedro había sacado en forma abusiva ese capital de los réditos arrojados por la hacienda que su amo le había encomendado, y que además, la anterior liberación alcanzada por cinco de sus hijos y una nieta a razón de 1.400 pesos, había sido también a expensas de la propiedad. Asimismo, alegó que cuando su extinto marido lo compró, no traía Román ningún patrimonio sino unos cortos bienes personales, y por consiguiente, creía confuso el origen de lo que afirmaba haber ahorrado en el periodo en que estuvo a su servicio.

94 Gutiérrez y Pineda, 1999, tomo II: 195. 
Bonifacia, por su lado, clamó a la justicia considerar que el Derecho en este caso debía privilegiar a los más «infelices» y no a una viuda llena de artimañas. Finalmente, en 1796 se dictaminó mantener en esclavitud a Pedro en vista de que no se logró probar que su amo le hubiera conferido licencia para comprar o contratar, y así, quedaba en entredicho el dinero por el cual su hija pretendía rescatarlo. De igual manera, tampoco se creyó justificada ninguna de las causales previstas por la ley para vislumbrar el beneficio de la manumisión ${ }^{95}$.

\section{REFLEXIONES FINALES}

La crisis de la institución de la esclavitud comenzó a ser palpable al finalizar el periodo colonial, prácticamente desde las postreras décadas del siglo XVIII. Este no fue un fenómeno aislado ni fortuito sino que coincidió con una desaceleración económica generalizada en todo el territorio del Nuevo Reino de Granada. La caída en la producción de los trapiches, las rebeliones, el aumento del cimarronismo, así como las crecientes tensiones entre amos y esclavos contribuyeron en alguna medida a profundizar esa situación ${ }^{96}$.

El advenimiento de las luchas independentistas de principios del siglo XIX tornaría aún más desesperanzador el destino de los esclavos, precisamente en tierras del nororiente donde se sintió con singular fuerza el fragor del conflicto. El reclutamiento forzoso, la participación en batallas, las largas travesías, las ventas precipitadas de esclavos para cumplir con la imposición de gravosas contribuciones, las confusiones reinantes en las declaratorias masivas de libertad, fueron solo algunas de las contingencias que aumentaron la incertidumbre y la distancia entre los miembros de las familias esclavas ${ }^{97}$.

Adicionalmente, dentro de las medidas fiscales habría que mencionar las órdenes de embargo impartidas tanto por el bando patriota como por el bando realista. Esas fluctuaciones e indefiniciones en la posesión legítima de caudales incidieron directamente en los esclavos, quienes al ser incluidos dentro del cúmulo de pertenencias confiscadas, fueron conminados a pasar incluso por varias manos, conforme al vaivén de las circunstancias. Una vez embargados, eran sometidos al avalúo y remate en pública almoneda al mejor postor o, de vez en cuando, pasaban a ser arrendados cuando hacían parte de los activos de las haciendas.

95 La liberta Bonifacia compra la libertad de su padre, 1796 (CDIHR), Causas Civiles, tomo años 1746-1749, f. 21v.

96 Jaramillo Uribe, I/1 (Bogotá, 1963): 50-55.

97 Hünefeldt, 2010: 287-289. 
En términos generales, y aún haciendo la salvedad metodológica respecto a las limitaciones de información, se puede concluir que el panorama del matrimonio y de la familia esclava fue descarnadamente difícil. Aquí el derecho de propiedad del amo limitó la aspiración natural del esclavo a construir una vida afectiva. Fue, en muchos aspectos, un desalentador ingrediente dentro de su ya azarosa vida cotidiana ${ }^{98}$. Sin embargo, las expresiones de gratitud y aprecio que fue factible encontrar en las relaciones entre amos y esclavos, así como la iniciativa de estos, ampliaron las posibilidades para lograr concesiones y beneficios en la vida conyugal y familiar.

Finalmente, el intenso mestizaje vivido en la zona - reflejado en la población esclava en el vertiginoso proceso de blanqueamiento-, así como el incremento de los casos de manumisión en cada una de sus diversas modalidades, fueron ofreciendo nuevos rumbos hacia la vida libre y con ello se abrían más esperanzas para integrar un hogar y establecer lazos afectivos, lejos de las ataduras propias del sistema esclavista. No obstante, esta condición de libertad entrañaba nuevos retos en medio de una sociedad que, aún después de culminado el dominio colonial, seguía imponiendo limitaciones a los descendientes afroamericanos.

\section{BiBLIOGRAFÍA}

Díaz Díaz, Rafael Antonio, Esclavitud, Región y Ciudad. El sistema esclavista urbano regional en Santa Fe de Bogotá 1700-1750, Bogotá, Pontificia Universidad Javeriana, 2001.

Dueñas Vargas, Guiomar, Los hijos del pecado, Bogotá, Universidad Nacional de Colombia, 1996.

Gonzalbo Aizpuru, Pilar, Familia y orden colonial, México D.F., El Colegio de México, 1998.

Gran Atlas y Geografia de Colombia, Bogotá, Intermedio Editores, 2004.

Grisanti, Ángel, El Precursor Neogranadino Vargas, Bogotá, Editorial Iqueima, 1951.

Gutiérrez de Pineda y Pineda Giraldo, Virginia y Roberto, Miscegenación y Cultura en la Colombia Colonial 1750-1810, Bogotá, Ediciones Uniandes, 1999, tomos I y II.

98 Aún cuando no se han encontrado testimonios concretos, es muy probable que este cúmulo continuado de barreras haya producido en el esclavo variaciones en su estado anímico, reflejadas en actitudes de rebeldía o de bajo rendimiento en sus obligaciones diarias de trabajo. 
Gutiérrez de Pineda, Virginia, La Familia en Colombia: trasfondo histórico, Medellín, Editorial de la Universidad de Antioquia, 1997.

Herrera Ángel, Marta, Ordenar para controlar. Ordenamiento espacial y control político en las Llanuras del Caribe y en los Andes Centrales Neogranadinos. Siglo XVIII, Bogotá, Icanh-Academia Colombiana de Historia, 2002.

Hünefeldt, Christine, «Esclavitud, percepciones raciales y lo político: la población negra en la era independentista en Hispanoamérica», Bonilla, Heraclio (ed.), Indios, negros y mestizos en la Independencia, Bogotá, Editorial Planeta-Universidad Nacional de Colombia, 2010: 270-289.

Jaramillo Uribe, Jaime, «Esclavos y señores en la sociedad colombiana del siglo XVIII», Anuario Colombiano de Historia Social y de la Cultura, I/1 (Bogotá, 1963): 35-38.

Klein, Herbert, La esclavitud africana en América Latina, Madrid, Alianza Editorial, 1986.

Konetzke, Richard, Colección de documentos para la historia de la formación social de Hispanoamérica, Madrid, Consejo Superior de Investigaciones Científicas, 1958, vol. I.

Las Siete Partidas del Rey Don Alfonso El Sabio, París, Imprenta de Panckoucke, 1846, tomo II.

Martínez Garnica, Armando, El Régimen del Resguardo en Santander, Bucaramanga, Gobernación de Santander, 1994.

Matos Hurtado, Belisario, Hechos y sucesos de la mía ciudad, Bucaramanga, Editorial Gómez y Páez, 1948.

Mörner, Magnus, La Corona española y los foráneos en los pueblos de indios de América, Estocolmo, Instituto de Estudios Iberoamericanos, 1970.

Mörner, Magnus, La mezcla de razas en la historia de América Latina, Buenos Aires, Editorial Paidós, 1969.

Mörner, Magnus, «Las comunidades de indígenas y la legislación segregacionista en el Nuevo Reino de Granada», Anuario Colombiano de Historia Social y de la Cultura, I/1 (Bogotá, 1963): 63-84.

Navarrete, María Cristina, «De amores y seducciones: el mestizaje en la Audiencia del Nuevo Reino de Granada en el siglo XVII», Memoria y Sociedad, VII/15 (Bogotá, 2003): 91-99.

Oviedo, Basilio Vicente de, Cualidades y Riquezas del Nuevo Reino de Granada, Bucaramanga, Imprenta Departamental de Santander, 1990.

Pacheco, Juan Manuel, «Constituciones Sinodales del Sínodo de 1606 celebrado por Don Bartolomé Lobo Guerrero», Ecclesiástica Xaveriana, V (Bogotá, 1955): 153201. 
Palacios de la Vega, Joseph, Diario de Viaje, Barranquilla, Universidad del Atlántico, 1994.

Pita Pico, Roger, «Amoríos entre amos y esclavas en Santander durante el periodo colonial», Estudio, 336 (Bucaramanga, 2007): 3-20.

Pita Pico, Roger, «La posesión de esclavos como soporte a las economías de sus amos en el nororiente neogranadino durante el siglo XVIII», Historia y Espacio, 31 (Cali, 2008): 89-115.

Recopilación de Leyes de los Reinos de las Indias, Madrid, Ediciones Cultura Hispánica, 1973, tomo II.

Rodríguez, Pablo, Sentimientos y vida familiar en el Nuevo Reino de Granada, Santa Fe de Bogotá, Editorial Ariel, 1997.

Romero Jaramillo, Dolcey, Esclavitud en la Provincia de Santa Marta 1791-1851, Santa Marta, Instituto de Cultura y Turismo del Magdalena, 1997.

Rueda Méndez, David, Esclavitud y Sociedad en la Provincia de Tunja, siglo XVIII, Tunja, Universidad Pedagógica y Tecnológica de Colombia, 1995.

Ruiz Hernández, Liliana Fabiola, Los esclavos en Girón 1789-1851, Bucaramanga, tesis UIS, 1994.

Saco, José Antonio, Historia de la esclavitud de la raza africana en el Nuevo Mundo y en especial en los países américo-hispanos, La Habana, Cultural S.A., 1938, tomo III.

Sæther, Steinar, Identidades e Independencia en Santa Marta y Riohacha 1750-1850, Bogotá, Icanh, 2005.

Sotelo Zárate, Mónica Johanna, «La población de Girón, Piedecuesta y Bucaramanga en la coyuntura de la Independencia, 1801-1830», Memorias, 2 (Bucaramanga, 2005): 9-34.

Zapata de Cárdenas, Luis (fray), Primer Catecismo en Santa Fe de Bogotá, Bogotá, Celam, 1988.

Fecha de recepción: 20 de febrero de 2011

Fecha de aceptación: 1 de septiembre de 2011 


\section{The «slavery» of feelings: the family and emotional life of the slaves in the northeast of the Nuevo Reino de Granada, 1720-1819}

Even on top of the established rules in the Nuevo Reino de Granada, the possibility of slaves establishing loving relationships or marrying always depended on the will and interests of the masters. Contact with free people brought certain complications to the slaves, but it also opened up greater opportunities for their emotional lives. The outlook for the slaves' family was not more encouraging. Trade dynamics, the manumission and other forms of slaves circulation represented a constant threat to the unity of these blood communities. There were many efforts and repeated pleas by those affected crying out for better conditions for a more stable emotional life.

KEY WORDS: slaves; family; marriage; colonial period; Nuevo Reino de Granada. 